\title{
WPS4500
}

\author{
Policy Research Working Paper 4500
}

Post-Conflict Transitions Working No. 18

\section{Health and Civil War in Rural Burundi}

Tom Bundervoet

Philip Verwimp

Richard Akresh

The World Bank

Development Research Group

Macroeconomics and Growth Team 
Policy Research Working Paper 4500

\begin{abstract}
This paper combines household survey data with event data on the timing and location of armed conflicts to examine the impact of Burundi's civil war on children's health status. The identification strategy exploits exogenous variation in the war's timing across provinces and the exposure of children's birth cohorts to the fighting. After controlling for province of residence,
\end{abstract}

birth cohort, individual and household characteristics, and province-specific time trends, the authors find that children exposed to the war have on average 0.515 standard deviations lower height-for-age z-scores than non-exposed children. This negative effect is robust to specifications exploiting alternative sources of exogenous variation.

This paper - a product of the Growth and the Macroeconomics Team, Development Research Group—is part of a research project entitled Post-Conflict Transitions focusing on development issues particularly relevant to countries recovering from conflict. Policy Research Working Papers are also posted on the Web at http://econ.worldbank.org. The author may be contacted at akresh@ad.uiuc.edu. 


\title{
Health and Civil War in Rural Burundi *
}

\author{
Tom Bundervoet ${ }^{1}$, Philip Verwimp ${ }^{2}$, and Richard Akresh ${ }^{3}$
}

Keywords: Child health, economic shocks, stunting, Africa

JEL classification: I12, J13, O12

\footnotetext{
* The authors would like to thank Peter Uvin, Robert Bates, Tony Addison, Olga Shemyakina and other participants at HiCN's first annual workshop as well as Marcel Fafchamps and participants to the CSAE conference for helpful comments on earlier drafts of the paper.

${ }^{1}$ Free University of Brussels; Research Affiliate, Households in Conflict Network

${ }^{2}$ Ecares, Université Libre de Bruxelles and Co-director Households in Conflict Network

${ }^{3}$ Department of Economics, University of Illinois at Urbana Champaign
} 


\section{Introduction}

During the past 30 years, civil conflict affected almost three-fourths of all countries in SubSaharan Africa. Recently academic economists and policy makers have begun focusing on this topic, specifically trying to understand the causes of war and its role in reducing growth and development (Collier and Hoeffler, 1998; Miguel, Satyanath, Sergenti, 2004; Guidolin and La Ferrara, forthcoming). Several researchers argue that wars do not have negative long-run economic consequences (see Davis and Weinstein (2002) for Japan; Brakman, Garretsen, and Schramm (2004) for Germany; Miguel and Roland (2006) for Vietnam; and Bellows and Miguel (2006) for Sierra Leone). Despite the suffering and deaths caused by these various conflicts, there is limited research that examines the microeconomic impacts of war, although this is slowly changing as data from war regions become available (Shemyakina, 2006). ${ }^{4}$

The 1990s were a particularly violent decade in Central Africa’s history. Burundi and Rwanda experienced several episodes of mass murder and genocide, and the regional civil war in the Democratic Republic of Congo created an enormous loss of life and socio-economic destruction. Most of the recent work on Burundi focuses on the causes of the latest episode of civil conflict (Nkurunziza and Ngaruko, 2000), the progression of the crisis (Chrétien and Mukuri, 2000), the year-by-year political dimensions of the conflict (Reyntjens and Vandeginste, 1997; Reyntjens, 1998), or the possible solutions to it (Ndikumana, 2000).

In this paper, we examine the impact of the Burundian civil war on the health status of children. ${ }^{5}$ We focus on chronic early childhood malnutrition and stunting measured by heightfor-age z-scores, and we examine if and how shocks, such as violent conflict, affect childhood health outcomes for those exposed children. We combine data from a nationally representative household survey (the 1998 Priority Survey carried out by the World Bank and the Burundi Statistics Institute) with event data on the timing and evolution of the conflict between 1994 and 1998. The empirical identification strategy exploits variation in the timing and duration of armed conflict across the Burundi provinces and the related variation determining which birth

\footnotetext{
${ }^{4}$ The number of people killed in direct violence is often less than the number killed by a conflict's indirect consequences, such as the breakdown of the economic and health systems and the spread of infectious diseases (WHO, 2002; Eck, 2003). Ghobarah, Huth, and Russett (2003) use cross-country data to assess the impact of civil wars on the loss of life and find that wars "continue to kill people indirectly, long after the shooting stops."

${ }^{5}$ Between 1990 and 2002, per capita income in Burundi fell from \$210 to \$110 leaving Burundi as the world's poorest country. The proportion of people living below the nationally defined poverty line increased from 35 percent to 68 percent, while international assistance declined from \$300 million to less than \$100 million.
} 
cohorts of children were exposed to the fighting (see Suri and Boozer (2007) who use a similar identification strategy to explore child labor and schooling issues). ${ }^{6}$ We find children who were exposed to the conflict have significantly lower height for age z-scores, an effect that is robust to the inclusion of a variety of control variables, time trends, and alternative sample specifications.

Recent research suggests this finding could have serious implications for the future schooling and productivity of these children when they reach adulthood. Alderman, Hoddinott, and Kinsey (2006) use Zimbabwe data and find that improvements in childhood chronic malnutrition (measured as height for age) are associated with a higher number of schooling grades completed. Alderman et al. (2001) estimate the impact of child health on school enrollment in rural Pakistan and conclude that improvements in preschool height for age z-scores are likely to have substantial long-run productivity effects through inducing greater schooling and subsequent productivity gains. Maccini and Yang (2006) and Meng and Qian (2006) find that negative early-life environmental conditions (negative rainfall shocks in Indonesia and China's Great Famine, respectively) lead to worse adult health and socioeconomic conditions.

There is also evidence demonstrating the adverse effects of prenatal health shocks. In research on the Dutch famine during World War II, Stein et al. (2004) examine the impact of prenatal exposure to the famine on body proportions at birth and find that exposure during late pregnancy negatively affected the child's birth weight and body proportions. Stein et al. (2007) have also studied the long-term consequences of the same famine and find that exposure during early pregnancy is associated with a higher risk of adult obesity for women. Similarly, Almond (2006) finds that children who were in utero during the 1918 influenza pandemic experienced lower educational attainment, increased rates of disability, and lower socioeconomic status once they reached adulthood. Based on this logic, it is likely the civil war in Burundi will have longrun welfare impacts through its adverse effect on child health which in turn can negatively affect schooling, future adult health, and income levels. Following the end of conflict, improved child health should be a tangible peace dividend, although there will still be a generation of children who were exposed to the conflict and have to suffer the negative consequences of the war.

\footnotetext{
${ }^{6}$ For the baseline regressions, we focus only on the provinces that experienced civil war at some point during this time period, and we exclude the two provinces in Burundi (Cankuzo and Rutana) that did not experience any conflict as these regions might be systematically different than regions where fighting occurred. In the robustness specifications that include these two provinces, results are quantitatively similar.
} 
The remainder of the paper is organized as follows. Section 2 provides an overview of the history of violence in Burundi and sketches the spatial and temporal event data for the most recent civil war. Section 3 describes the survey data used in the analysis and explains the key variables. Section 4 describes the empirical identification strategy and section 5 presents the main results as well as robustness tests. Section 6 concludes.

\section{Conflict in Burundi}

\subsection{Political History}

Civil conflict in Burundi began in 1965, three years after independence from the Belgian colonial administration, when a group of Hutu officers unsuccessfully tried to seize power and overthrow the monarchy. This failed coup led to a purge of Hutu from the army and government and marked the beginning of political exclusion of the Hutu majority by the Tutsi minority. Power became the sole monopoly of the Tutsi, who effectively seized power in 1966 and proclaimed the First Republic, headed by Captain Micombero. During Micombero’s regime, power became increasingly concentrated in the hands of the Tutsi Hima clan, a small ethno-regional group from the southern province of Bururi, that the French historian Chrétien calls the Bururi mafia (1997).

In 1972, a Hutu insurgency started in southwestern Burundi resulting in considerable loss of life among the Tutsi residents. The subsequent Tutsi army repression was dramatic. From May to August 1972, all educated Hutus and members of the Hutu elite were systematically eliminated or fled into exile (Lemarchand, 1994). This massacre of educated Hutus reduced their status to an oppressed underclass and reduced future Hutu opposition for over a generation.

The next major violent confrontation took place in 1988, when a Hutu insurgency was launched in the north of the country. ${ }^{7}$ As in 1972, army repression was swift and took a heavy toll on the local Hutu population. However, contrary to 1972, this time the international community condemned the massacres and put pressure on the Buyoya regime to liberalize its political system. This led, in June 1993, to the first free and fair elections in post-independence Burundi. ${ }^{8}$ Unfortunately, this democratic transition did not last. In October 1993, Melchior

\footnotetext{
${ }^{7}$ In the intervening years, Colonel Bagaza replaced Micombero in a palace coup in 1976, and then he was ousted by Major Buyoya in another bloodless coup in 1987. Both leaders are Tutsi and from Bururi.

${ }^{8}$ The elections resulted in a landslide victory for the opposition party, Frodebu, with 65 of 81 Parliament seats and 64 percent of all votes in the presidential elections (Reyntjens, 1993).
} 
Ndadaye, the first democratically elected president and a Hutu civilian, was assassinated by Tutsi army elements in a failed coup attempt, marking the start of yet another civil war.

As news of the president's assassination spread to the rural provinces, Hutu peasants committed large-scale massacres of Tutsi civilians and Uprona Hutus. ${ }^{9}$ Chrétien (1997) describes the massacres saying that districts in certain provinces were "almost completely 'cleansed' of all Tutsi elements.” ${ }^{10}$ In a matter of days, approximately 100,000 Burundians lost their lives in what were later acknowledged as acts of genocide (United Nations, 1996; Nkurunziza and Ngaruko, 2000). The Tutsi army retaliated against the Hutu population, continuing what would become the most severe civil war in Burundi's history, both in terms of human lives and socioeconomic destruction. Unlike previous wars that all started with a localized Hutu insurgency followed by severe but random Tutsi army reprisals, this crisis was a more traditional war, with two opposing armed and organized factions and an impact on almost the entire country (Ndikumana, 2000).

\subsection{Spatial and Temporal Intensity of the Conflict}

In this analysis of child health, the exact timing and location of the war plays an important role. We describe the war's evolution through time and space as follows:

- October to December 1993: Failed coup d'état followed by large-scale massacres in the north and center of the country.

- January 1994 to July 1996: Spread of civil war throughout the country (see Figures 1 and 2).

- July 1996 to August 2000: Return of Major Buyoya to power after a bloodless coup. Lower civil war intensity in most provinces and signing of the Arusha Peace Accords in 2000.

Figure 1 sketches a more detailed evolution of the conflict, defined at the province-month level. $^{11}$ Guerrilla warfare activity first erupted in October 1994 in the northwestern provinces of Cibitoke, Bubanza, Bujumbura Rural and Ngozi. By early 1995, violence spread to the bordering Kayanza province, and by March 1995, massacres of civilians and confrontations between the army and rebel forces began in Karuzi, Bururi, Ruyigi and Muyinga. On March 27,

\footnotetext{
${ }^{9}$ Uprona Hutus are Hutus loyal to the former unique state party, Uprona, and are therefore seen as traitors to the Hutu cause. Consult Chrétien and Mukuri (2000) for an overview of the massacres that followed the coup.

${ }^{10}$ Authors' translation from French.

11 The crisis reconstruction is largely based on the work of Chrétien and Mukuri (2000) and the U.N. (1996).
} 
1995, Burundi’s interim president, Sylvere Ntibantunganya, announced the start of a genocide on Belgian television (Chrétien and Mukuri, 2000). By late 1995, acts of violence took place in the central provinces of Gitega and Muramvya and the northern province of Kirundo. The situation at the end of 1995 is depicted in Figure 2. By then, the conflict had spread to almost all of the provinces of Burundi, with the exception of Cankuzo (in the east of the country) and Rutana and Makamba (in the south of the country). ${ }^{12}$ On July 25, 1996, former president Buyoya seized power again in a bloodless coup d'état backed by the army. During the second half of 1996 and the first half of 1997, armed confrontations continued, especially in the provinces of Kayanza, Muramvya, Kirundo and Gitega. Meanwhile in April 1997, the Arusha Peace talks between the principal parties engaged in the conflict began. As of late 1997, insecurity increased again in Cibitoke, Bubanza and Bujumbura rural, provinces which remained unsafe until 1999.

Although the Arusha peace negotiations were successfully concluded in August 2000, and a transitional government was established in 2002, it was not until 2003 that Burundi entered a period of fragile peace. ${ }^{13}$ By 2005, a new constitution was approved and communal and parliamentary elections were held. In September 2006, the final rebel group, FNL, signed a cease-fire agreement with the government finally ending the civil war. Coupled with this political stability, a series of structural reforms were implemented to stabilize the economy, and post-2000 GDP growth rates averaged 2.7 percent per year. Despite these political and economic improvements after 2000, health issues in general and child health in particular remain a major concern in post-conflict Burundi.

\section{1998 Burundi Priority Survey}

\subsection{Data Overview}

The Burundi Priority Survey took place between October 1998 and March 1999 and was organized by the Burundi Institute of Statistics and Economic Studies in cooperation with the World Bank. The survey's main goal was to evaluate the country's socioeconomic situation following five years of civil war in order to design an efficient poverty alleviation policy (Republic of Burundi, 1998). The survey was designed to be nationally representative, but

\footnotetext{
${ }^{12}$ By late 1998, Makamba was severely impacted by insurgents operating from neighboring Tanzania. Due to the generalized insecurity in Makamba at the time of the survey, no data were collected (Republic of Burundi, 1998). ${ }^{13}$ Since the 2000 Arusha agreements were not signed by the two main rebel groups, CNDD-FDD and FNL, these agreements had no real impact in the field.
} 
insecurity in the countryside meant certain regions could not be surveyed. The entire province of Makamba was excluded and parts of Bubanza and rural Bujumbura were excluded, leaving a total sample of 3,908 rural households. These rural households have 1,442 children between 6 and 60 months of age. Since our identification strategy exploits the variation in the timing and duration of the conflict in a given province, we exclude two groups of children from the baseline regressions. We exclude 129 children in Cankuzo and Rutana, provinces that did not experience any armed conflict, and 85 children in Bubanza, Bujumbura Rural, and Cibitoke, provinces in which all children were exposed to the war. In addition, there are 201 children that cannot be used in the analysis since the survey is missing information on either their height or age. This leaves a final sample of 1,027 children between 6 and 60 months of age. ${ }^{14}$

\subsection{Health and Civil War Variables}

Childhood health status has multiple dimensions that make it difficult to capture in a single indicator. ${ }^{15}$ The relevant literature suggests that child height conditional on age and gender can be objectively measured and is a good indicator of long-run nutritional status as height reflects the accumulation of past outcomes (Martorell and Habicht, 1986). Because the goal of our analysis is to estimate the impact of the conflict (which started in October 1993) on the health status of children in October 1998 (the time of the survey), we focus on the long-run indicator, child height for age. ${ }^{16}$ We compute z-scores for each child's height for age, where the z-score is defined as the difference between the child's height and the median height of the same-aged American reference population, divided by the standard deviation of the reference population. On average, across households in all of rural Burundi, children were more than two standard deviations below the average height for age of an American child.

To construct the civil war shock variable for the analysis, we examine, based on Figure 1, whether a specific child was directly exposed to the war during his life. The variable is defined at the province times birth cohort level, (Conflict Province ${ }_{j}^{*}$ Alive During Conflict $_{t}$ ), which allows us to exploit variation across two dimensions: spatial (variation across provinces) and

\footnotetext{
${ }^{14}$ The large number of children with missing height or age information potentially poses a selection bias problem. However, in Appendix A, we explore this issue in greater detail and find that along observable dimensions, included and excluded children are similar. Using regression analysis similar to Fitzgerald, Gottschalk, and Moffit (1998), we conclude the civil war shock is not correlated with being included in the sample.

${ }^{15}$ See Strauss and Thomas (1995) for a review of different health indicators used in the empirical literature.

${ }^{16}$ Research has found that children with different racial and ethnic backgrounds follow similar growth curves, so an unusual negative deviation from this growth path can be attributed to insufficient nutritional intake.
} 
temporal (within each province, the timing of birth and the timing of the conflict). For the baseline regressions restricted to those provinces that all experienced conflict, we only exploit the timing of the crisis and not the comparison between conflict and non-conflict provinces. However, we define the civil war shock variable in this way since in the robustness specifications, we incorporate the two non-conflict provinces and make use of the spatial variation across regions. Within a given province that experienced war, the civil war shock variable for a child who was born before or during the conflict is coded one, while the variable is coded zero for a child not alive during the war. Of the 1,027 rural children in the baseline sample, 657 were exposed to the civil war during their lives.

\subsection{Preliminary Observations}

Table 1 shows the provincial disparities in nutritional status (average height for age z-score) and the incidence of malnutrition. ${ }^{17}$ The first salient factor in Table 1 is the magnitude of malnutrition: 58.8 percent of all children in the sample are malnourished with 32.8 percent experiencing severe malnutrition. There is variation across provinces in the level of malnutrition with rates varying from 34.9 percent in Bururi to 77.1 percent in Kayanza. The average heightfor-age z-score in rural Burundi is -2.28, meaning that an average child in rural Burundi has a height-for-age that is 2.28 standard deviations lower than an average American child.

In Table 2 Panel A, we present, broken down by province, the average height for age zscores for children who are not exposed to the civil war (column 1) and for children who are exposed to the war (column 2). The 657 children exposed to the war have an average height for age z-score of -2.588, while the remaining 370 children not exposed to the conflict during their lives show an average z-score of -1.844 . This difference of 0.744 standard deviations is statistically significant at the one percent level. For every province, children exposed to the war have lower height for age z-scores than the children from that same province who are not exposed to the war, and for most provinces the difference is statistically significant at the one percent level. Although these results suggest the conflict had an adverse effect on child health, many factors influence health and we cannot yet conclude this is a causal relationship.

\footnotetext{
${ }^{17}$ The incidence of malnutrition is divided into 3 groups: not malnourished (z-score $\geq-2$ ), moderately malnourished
} $(-3 \leq$ z-score $<-2)$ and severely malnourished (z-score $<-3)$. 


\section{Identification and Econometric Specification}

It is well-known that height for age follows a non-linear pattern in developing countries, with older children having worse z-scores than younger ones (Martorell and Habicht, 1986). Since height for age is a stock variable, reflecting both current and past health investments, older children accumulate a larger deficit during their lives, resulting in lower height for age compared to younger children. Panel B in Table 2 indicates that children exposed to the conflict are older than non-exposed children (40.17 compared to 15.49 months). Therefore, the relationship between conflict and height seen in Panel A may simply reflect that children exposed to the conflict are on average older than non-exposed children. We next present preliminary evidence that the conflict-health relationship is not due to this differential age pattern.

In the second row of Table 2 Panel B, we compare average height for age $\mathrm{z}$-scores for children exposed and not exposed to the civil war but restricted to children less than or equal to 24 months old. The average height for age z-scores for young exposed children is -2.526, while it is -1.824 for young non-exposed children. The difference between exposed and non-exposed young children of 0.702 standard deviations is statistically significant at the one percent level. The same pattern is seen if the data are restricted to children greater than 24 months old. In the third row of Table 2 Panel B, older children exposed to the war have an average height for age zscore of -2.592, while older children not exposed to the war have an average height for age zscore of -2.065 . There is a difference of 0.527 standard deviations between exposed and nonexposed older children and this difference is significant at the ten percent level. These results provide preliminary evidence that the impact of conflict on health is not solely due to older children being more likely to be exposed to the war, as the results within each age category show a large significant war impact on children's height for age z-scores. In the subsequent regression analysis, we control for potential age effects by including year of birth fixed effects.

Related to the non-linear age pattern and its relationship with conflict and health is the role of poverty as a potential alternative explanation for the war-health link. Following Duflo's (2003) argument, older children in poor regions (or households) are shorter than older children in non-poor regions because they accumulate a larger poverty-induced height deficit. Conversely, younger children in poor regions will look more similar in height to younger children in nonpoor regions because they have not had time to develop large height deficits. Therefore, if the 
war affected mostly poor provinces, then we would falsely attribute this observed lower height for age z-score to the war, when in fact it is due to the region's poverty status.

In the first row of Panel $\mathrm{C}$ in Table 2, we present average height for age z-scores for exposed and non-exposed children in the poor provinces only. A province is defined as being poor if the 1990 pre-war poverty headcount (percentage poor) is above the national average of 36.2 percent. ${ }^{18}$ Within the poor provinces, children who are exposed to the civil war have an average height for age z-score of -2.672, while children in poor provinces not exposed to the civil war have an average height for age z-score of -1.939. The difference of 0.733 standard deviations is statistically significant at the one percent level. Similarly, within non-poor provinces, children exposed to the conflict have 0.790 standard deviations lower height for age zscores than non-exposed children, a difference that is statistically significant at the one percent level. These results suggest that poverty is unlikely to be the driving force behind the observed lower height for age z-scores of children in civil war regions.

Several additional pieces of evidence indicate that children exposed to the war were not living in predominantly worse-off provinces. First, in Table 3, results show a higher percentage of children were exposed to the civil war in the non-poor provinces compared to the poor provinces (68.02 versus 60.96) and the difference across regions is statistically significant at the five percent level. Second, provinces that experienced fighting in the earlier years had lower average poverty headcount rates than provinces that became involved in the war in the later years (31.16 versus 37.99 percent). Third, when the war started in 1994, the first affected provinces (Cibitoke, Bubanza, and Bujumbura Rural) were among the richest in Burundi and were ranked first, second, and fifth respectively in a 1990 pre-war welfare ranking (Republic of Burundi, 2003). Taken together, this evidence strongly suggests that children exposed to the war were not predominantly in worse-off provinces and that conflict may have had a negative causal impact on their health. In the subsequent regression analysis, we include province fixed effects to control for any potential province differences.

The empirical identification strategy can be illustrated by examining the nonparametric relationship between height for age z-scores and the number of months of exposure to the civil war. In Figure 3, we estimate a kernel-weighted local polynomial regression of height for age z-

\footnotetext{
18 Table 1 column 6 presents the pre-war poverty headcount for each province with variation ranging from Karuzi with 66.8 percent of the population in poverty to Cibitoke with a 19.6 percent rate (Bundervoet, 2006).
} 
scores on months of war exposure using an Epanechnikov kernel. The figure shows a sharp drop in average height for age z-scores as children are exposed to the fighting. The gap stays roughly constant from 3 to 20 months of war exposure, and then drops further as months of exposure increases beyond 20 months.

To build on Figure 3 and the previous tabulations, we first estimate the following baseline province and birth cohort fixed effects regression:

$$
H A Z_{i j t}=\alpha_{j}+\delta_{t}+\beta_{1}\left(\text { Conflict } \text { Province }_{j} * \text { Alive During Conflict } t\right)+\varepsilon_{i j t}
$$

where $H A Z_{i j t}$ is the height for age z-score for child $i$ in province $j$ who was born in time period $t$, $\alpha_{j}$ are the province fixed effects, $\delta_{t}$ are the year of birth cohort fixed effects, Conflict Province ${ }_{j}{ }^{*}$ Alive During Conflict ${ }_{t}$ indicates a child born in a province that experienced conflict and who was alive during the war, and $\varepsilon_{i j t}$ is a random, idiosyncratic error term. ${ }^{19}$ The coefficient $\beta_{1}$ measures the impact of civil war on children's health for children who were alive during the conflict and living in regions that experienced this negative shock. In the baseline regressions that are restricted to only those provinces that experienced conflict, identification of the impact comes from comparing, within a given province, children who were alive during the war with those not yet born, and therefore only the timing of the conflict is exploited. This is done because the two provinces that did not experience civil war might be systematically different than those provinces that did experience conflict. In the robustness specifications, we include the provinces that did not experience conflict and are therefore able to also take advantage of regional variation. For the robustness regressions, we are evaluating whether children born in conflict provinces in years when fighting was taking place have lower height for age z-scores than their peers born after them, relative to those who are born in other regions in the same year.

The identification strategy is valid as long as changes over time in average height for age z-scores would be similar across provinces in the absence of the war. Specifically, the strategy might be flawed if the timing or duration of the conflict followed a particular pattern in terms of province-level characteristics that are related to changes in height for age z-scores. For instance, if the provinces that experienced the fighting in the earlier years had less educated households and education is correlated with children's height for age, then we would wrongly find an effect of the war, when the negative health impact was really due to education differences across the

\footnotetext{
${ }^{19}$ Correlation among the error terms of children in a given province experiencing the same shocks might bias the OLS standard errors downward, so in all regressions we cluster the standard errors by birth province (Moulton, 1986; Bertrand, Duflo, and Mullainathan, 2004).
} 
provinces. In Table 4, we assign provinces into two categories based on Figure 1 (early and late civil war) and find that along observable dimensions, provinces that experienced fighting in the earlier years do not appear to differ from provinces that became involved in the war in the later years. ${ }^{20}$ There are no statistically significant differences across early and late civil war provinces in household-level characteristics (percentage of literate mothers, percentage of head of households with education, and head of household's age and marital status) or child-level characteristics (child's age, child's gender, and percentage exposed to the civil war). ${ }^{21}$

The baseline regressions do not control for province specific time trends that might influence children's height for age z-scores and could invalidate the identification strategy. To address this, we estimate the following equation that includes a province trend in addition to province and birth cohort fixed effects (for a similar empirical strategy see Banerjee et al, 2007):

$$
H A Z_{i j t}=\alpha_{j}+\delta_{t}+\beta_{1}\left(\text { Conflict } \text { Province }_{j} * \text { Alive During Conflict } t\right)+\text { Province Trend }_{j t}+\varepsilon_{i j t}
$$

where the variables are as previously defined and Province Trend ${ }_{j t}$ is defined three ways. First, the province trend tests for the presence of a differential time trend across poor and non-poor provinces. Second, the provinces are divided into separate war regions based on the groupings in Figure 1 and we test for a differential time trend across these war regions. Third, we use a more flexible province specific time trend to capture potentially different time patterns in each province. The inclusion of these measures buttresses the argument that changes in average height for age z-scores in these provinces would have been similar in the absence of the civil war.

\section{Empirical Results}

\subsection{Baseline Regressions}

Table 5 presents the regression results for equations 1 and 2. Each regression includes province and year of birth cohort fixed effects and is weighted using survey sampling weights. The variable of interest is the civil war conflict shock that indicates a child born in a province that

\footnotetext{
${ }^{20}$ Ngozi and Kayanza (groups 1 and 2 in Figure 1) are labeled early civil war provinces since the war started there by January 1995. Ruyigi, Karuzi, Muyinga, Bururi, Muramvya, Kirundo, Gitega (groups 3 and 4) are labeled late civil war provinces as the war did not start there until mid-1995. Bubanza, Bujumbura Rural, and Cibitoke (group 5) are not included in the baseline analysis as all children in these provinces were exposed to the conflict. Results are robust to alternatively putting the group 3 provinces (where the war started in mid-1995) in the early civil war category and leaving the group 4 provinces (where the war did not start until late 1995) in the late civil war group.

${ }^{21}$ In results not shown, the two provinces, Cankuzo and Rutana, which did not experience any armed conflict, look similar along these observable dimensions to the early and late civil war regions. The three provinces, Bubanza, Bujumbura Rural, and Cibitoke, in which all children were exposed to the conflict, also look similar along these observable dimensions to the early and late civil war regions.
} 
experienced conflict and who was alive during the war. For these baseline regressions in Table 5 , since all of these provinces experienced conflict at some point during this time period, we only exploit the timing and duration of the crisis and the related exposure of a child to the war. This leaves a sample of 1027 children, of which 657 were exposed to the conflict. Results in column 1 show a strong negative impact of the civil war on children's health. Those children who were exposed to the war have a height for age z-score 0.618 standard deviations lower than nonexposed children, a reduction that is statistically significant at the one percent level. ${ }^{22}$

The child development literature suggests child stunting usually occurs between 6 and 24 months of age and is considered permanent, with minimal catch-up growth at older ages (Martorell and Habicht, 1986; Martorell, Khan, and Schroeder, 1994). As a robustness check to the column 1 regression, we use an alternative conflict shock definition in which only children aged 6 to 24 months old when the conflict occurred in their province are considered exposed to the shock. In this manner, children older than 24 months in a province that experienced conflict are not considered exposed to the war. ${ }^{23}$ Results in column 2 are similar to the baseline model with children who are exposed to the war having 0.435 standard deviations lower height for age z-scores, and the coefficient is significant at the five percent level.

In column 3, we include additional household controls in the regression, such as the child's gender, whether the head of household is educated, whether the child is in a femaleheaded household, and the head of household's age and marital status. The coefficient on the civil war shock is unchanged from the column 1 regression and remains significant at the one percent level. Results indicate a strong positive association between height for age z-scores and the child's gender, with girls having improved height for age z-scores. ${ }^{24}$ In addition, children in households with educated heads have better height for age z-scores. ${ }^{25}$

\footnotetext{
${ }^{22}$ Our analysis is likely to underestimate the conflict's true health effect since we do not have data for children who died prior to the 1998 survey. The reported effects are thus likely to be lower bounds of the true impact and should be interpreted as the war's impact on a child's health, conditional on the child surviving to be recorded in the survey. ${ }^{23}$ With this alternative conflict shock definition, 349 of the 1027 children are in this restricted age range and live in a province that experienced civil war.

${ }^{24}$ A similar gender effect is also found by Thomas, Lavy, and Strauss (1996) in their analysis of anthropometric outcomes in Côte d'Ivoire, although in their study, the association is weaker. We test for dependency between the civil war shock and gender but the interaction is not statistically significant.

${ }^{25}$ The positive correlation between parental education and child health is among the most persistent findings in the empirical literature on child health production functions (see Rosenzweig and Schultz (1982) and Strauss and Thomas (1995) for an overview of this literature).
} 
These baseline regressions provide evidence of a negative causal impact of conflict on children's height for age, controlling for province and birth cohort fixed effects, but these results could be due to omitted province specific trends. For this reason, in columns 4, 5, and 6, we estimate equation 2 and include three alternative province specific trends in addition to province and birth cohort fixed effects. Column 4 presents the results of a regression including the poorregion specific time trend. Results still indicate a large negative impact of the war on children exposed to the conflict, with those children having 0.576 standard deviations lower height for age z-scores, and the result is significant at the five percent level. Column 5 presents the results of a regression including the time trend based on the war region groupings in Figure 1. Children exposed to the conflict experience 0.551 standard deviations lower height for age z-scores and the coefficient is significant at the one percent level. Finally, in column 6, we control in a more flexible manner for the potentially differential time trend for each province. Controlling for the province specific time trend in this way yields consist results, with exposed children experiencing 0.515 standard deviations lower height for age z-scores, and the coefficient is significant at the five percent level. The regressions in columns 4, 5, and 6 provide the strongest evidence that those children exposed to the civil war experienced a negative impact of the fighting that lowered their height for age z-scores.

\subsection{Alternative Sample Specifications}

For the previous baseline regressions, the province sample has been restricted to only those provinces that experienced war for some portion of the five year time period. This means that the identification of the war impact comes only from the timing and duration of the fighting. In Table 6, we present a series of robustness specifications based on the inclusion of children from provinces that were previously excluded from the baseline regressions in Table 5. All of these regressions also include the 1027 children used in the Table 5 regressions.

There are three sets of alternative sample specifications that we estimate. First, in columns 1 and 2, we include the three provinces (Bubanza, Bujumbura Rural, and Cibitoke) in which all children in those provinces were exposed to the war. These provinces experienced conflict from late 1994 until mid-1995 and then again starting in late 1997 until the survey was conducted in late 1998. Therefore, in these provinces there are no non-exposed children. Results in columns 1 and 2 indicate that exposure to the conflict lowered height for age z-scores by 0.543 
or 0.545 standard deviations respectively for the regressions without or with province specific time trends.

Second, in columns 3 and 4, we include the two provinces (Cankuzo and Rutana) that did not experience any fighting and so had no children exposed to the war. These two provinces could be systematically different than those provinces that did experience civil war, which is why they were excluded from the baseline regressions. Including them in the analysis allows us to now take advantage of regional variation between conflict and non-conflict provinces. With these provinces included, we are now evaluating whether children born in conflict provinces in years when war occurred have lower height for age z-scores than their counterparts born after the war ended, relative to those children born in non-conflict provinces in the same year. Results in column 3 and 4 are similar to the baseline regressions. Children exposed to the conflict have 0.512 standard deviations lower height for age z-scores in the regression without the province specific time trend and 0.492 standard deviations lower height for age z-scores in the regression with the province specific time trend.

Third, we include the children from the three provinces (Bubanza, Bujumbura Rural, and Cibitoke) in which all children were exposed to the war plus the children from the two provinces (Cankuzo and Rutana) in which no children were exposed to the war. Results in column 5 and 6 are similar to previous results. Children exposed to the conflict experience 0.472 or 0.521 standard deviations lower height for age z-scores and the coefficients are statistically significant at the one and five percent levels, respectively. Results in Table 6 provide convincing evidence of the validity of the identification strategy and the lack of any province-level selection bias in exploiting only the variation across provinces in the timing and duration of the conflict to calculate the causal impact of civil war on children's health status.

\section{Conclusions}

The health status of children in Burundi is poor. The average height for age z-score is 2.28 standard deviations below the average American child and 59 percent of all children are moderately or severely malnourished. In this paper, we combine detailed event data about the timing and location of armed conflict with household survey data to examine the impact of the civil war in Burundi on the health status of young children who were exposed to it. The empirical identification strategy exploits variation in the timing of the war across Burundi's 
provinces and the related variation in which birth cohorts of children were exposed to the fighting. We estimate a standard health production function with cohort of birth fixed effects, province of residence fixed effects, and province specific time trends and find that the civil war had a significant adverse effect on height for age z-scores. Children who were exposed to the violence during their lives have a height for age z-score that is between 0.515 and 0.618 standard deviations lower, depending on the specification, than that of non-exposed children. This causal effect of war on children's health is robust to the inclusion of a variety of household level control variables, different time trends, and alternative sample specifications that exploit the variation in conflict/non-conflict regions in addition to the variation in the timing of the crisis.

The poor health status of Burundian children could lead to adverse welfare effects in the long-run. Recent research based on panel data analysis has shown that chronic malnutrition during childhood (measured by height for age) is associated with substantially less schooling during adolescence, worse adult health, and lower adult productivity. Hence, it is likely that the civil war, by negatively affecting child health, will reduce the future welfare levels of these children. 


\section{Appendix A: Potential Selection Bias for Missing Children}

The 3908 rural households included in the Priority Survey provide data on 1442 children between 6 and 60 months of age. As shown in Appendix Table 1, the three provinces in which all children were exposed to the war (Bubanza, Bujumbura Rural, and Cibitoke) and the two provinces in which no children were exposed to the war (Cankuzo and Rutana) are excluded from the baseline analysis. There are 85 and 129 children, respectively, in these two regions, which leaves a total rural sample of 1228 children. An additional 166 children cannot be included in the child health analysis because of missing height data. ${ }^{26}$ There are 35 children excluded from the analysis due to measurement errors in either height or age (for instance a height of $775 \mathrm{~cm}$ for a 16-month old child). ${ }^{27}$ This large number of children (201) with missing information potentially poses a selection bias problem. We use two alternative approaches to evaluate this problem and find consistent results indicating selection bias is unlikely to be a significant concern.

The first approach is to compare the 1027 children who were included in the analysis with the 201 excluded children along as many observable dimensions as possible. Results for this comparison are presented in Appendix Table 2, which shows the mean differences in covariates for the included and excluded children. The children appear to come from similar types of households, with the percentage of literate mothers, household head's education level, age, and marital status not showing any significant differences across the two groups. Average age and gender of the child also appear to be similar for both groups of children. Finally, the excluded children are no more likely to have been exposed to the civil war shock. Since none of the covariates are significantly different across the two groups of children, this suggests that, at least along observable dimensions, selection effects are likely to be minimal or absent.

The second approach modifies the method proposed by Fitzgerald, Gottschalk, and Moffit (1998) to analyze attrition in a panel data setting. In Appendix Table 3, we present results of a probit regression analysis where the dependent variable is the probability of being included in the sample. For the 1027 children included in the health analysis, the variable is coded one and for

\footnotetext{
${ }^{26}$ The survey does not provide any reason for this non-measurement of certain children.

${ }^{27}$ We adopt the approach of Alderman, Hoddinott, and Kinsey (2006) in excluding all children with a z-score of less than -6 or greater than 6 , as these extreme scores are probably due to measurement errors.
} 
the 201 excluded children, it is coded zero. We examine whether the civil war shock influences the probability of being included in the sample. If the shock has a significant impact on the probability of being included, then the parameter estimates in our subsequent analysis are likely to be biased. In column 1, we estimate the probability of being included in the sample as a function only of the civil war shock, and the resulting coefficient is small and insignificant. In column 2, we add province and birth cohort fixed effects, as in Table 5, and the coefficient for the civil war shock remains insignificant. Finally, in column 3, in addition to province and birth cohort fixed effects, we include a province specific time trend. The civil war coefficient remains insignificant. From these results, we conclude that the civil war does not have a significant impact on the probability of being excluded from the sample and therefore any selection effects are likely to be small. 


\section{References}

Alderman, H., Behrman, J., Lavy, V. and Menon, R. (2001). “Child Health and School Enrollment: A Longitudinal Analysis.” Journal of Human Resources, 36(1), 185-205.

Alderman, H., Hoddinott, J., and Kinsey, B. (2006). “Long Term Consequences of Early Childhood Malnutrition.” Oxford Economic Papers, 58(3), 450-474.

Almond, D. (2006). "Is the 1919 Influenza Pandemic Over? Long-Term Effects of In Utero Influenza Exposure in the Post-1940 U.S. Population.” Journal of Political Economy, 114(4), $672-712$.

Banerjee, A., Duflo, E., Postel-Vinay, G., Watts, T. (2007). “Long Run Health Impacts of Income Shocks: Wine and Phylloxera in $19^{\text {th }}$ Century France.” NBER Working Paper 12895.

Bellows, J. and Miguel, E. (2006). “War and Local Collective Action in Sierra Leone.” UC, Berkeley, manuscript.

Bertrand, M., Duflo, E., and Mullainathan, S. (2004). “How Much Should We Trust Differencein-Differences Estimates?” Quarterly Journal of Economics, 119(1), 249-275.

Brakman, S., Garretsen, H., and Schramm, M. (2004). “The Strategic Bombing of German Cities During World War II and Its Impact on City Growth.” Journal of Economic Geography, 4(2), 201-218.

Bundervoet, T. (2006). “Estimating Poverty in Burundi.” Households in Conflict Network Working Paper No. 20.

Chrétien, J. (1997). Le Défi de l’Ethnisme: Rwanda et Burundi: 1990-1996. Karthala. Paris.

Chrétien, J. P. and Mukuri, M. (2000). Burundi, la Fracture Identitaire. Logiques de Violence et Certitudes 'Ethniques’, (1993-1996). Karthala. Paris. 
Collier, P. and Hoeffler, A. (1998). “On the Economic Causes of Civil War.” Oxford Economic Papers, 50(4), 563-573.

Davis, D., and Weinstein, D. (2002). "Bones, Bombs, and Break Points: The Geography of Economic Activity.” American Economic Review, 92(5), 1269-1289.

Duflo, E. (2003). "Grandmothers and Granddaughters: Old Age Pensions and Intra-household Allocation in South Africa.” World Bank Economic Review, 17(1), 1-25.

Eck, K. (2003). “Collective Violence in 2002 and 2003.” In States in Armed Conflict 2003. L. Harbom, Editor. Uppsala University: Department of Peace and Conflict Research.

Fitzgerald, Gottschalk and Moffit, R. (1998). “An Analysis of Sample Attrition in Panel Data.” Journal of Human Resources, 33(2), 251-299.

Ghobarah, H., Huth, P., and Russett, B. (2003). "Civil Wars Kill and Maim People Long After the Shooting Stops.” American Political Science Review, 97(2), 189-202.

Guidolin, M. and La Ferrara, E. (Forthcoming). "Diamonds are Forever, Wars Are Not. Is Conflict Bad for Private Firms?” American Economic Review, forthcoming.

Lemarchand, R. (1994). Burundi: Ethnocide as Discourse and Practice. Cambridge University Press. Cambridge.

Maccini, S., and Yang, D. (2006). "Under the Weather: Health, Schooling, and Socioeconomic Consequences of Early-Life Rainfall.” University of Michigan, manuscript.

Martorell, R. and Habicht, J. (1986). "Growth in Early Childhood in Developing Countries.” In Human Growth: A Comprehensive Treatise. F. Falkner and J. Tanner, Editors. Plenum Press. New York. 
Martorell, R., Khan, L. K., and Schroeder, D. (1994). "Reversibility of Stunting:

Epidemiological Findings in Children from Developing Countries." European Journal of Clinical Nutrition, 48(1), 45-57.

Meng, X and Qian, N. (2006). “The Long Run Health and Economic Consequences of Famine on Survivors: Evidence from China’s Great Famine.” CEPR Discussion Paper No. 5989.

Miguel, E., and Roland, G. (2006). “The Long Run Impact of Bombing Vietnam.” University of California, Berkeley manuscript.

Miguel, E., Satyanath, S., Sergenti, E. (2004). "Economic Shocks and Civil Conflict: An Instrumental Variables Approach.” Journal of Political Economy, 114(4), 725-753.

Moulton, B. (1986). "Random Group Effects and the Precision of Regression Estimates.” Journal of Econometrics, 32(3), 385-397.

Ndikumana, L. (2000). "Towards a Solution to Violence in Burundi: A Case for Political and Economic Liberalization.” Journal of Modern African Studies, 38(3), 431-459.

Nkurunziza, J. and Ngaruko, F. (2000). “An Economic Interpretation of Conflict in Burundi.” Journal of African Economies, 9(3), 370-409.

Republic of Burundi. (1995). Note de Stratégie Economique et Evaluation de la Pauvreté. Report No. 13592. Bujumbura, Burundi.

Republic of Burundi (1998). Enquete Prioritaire: Etude Nationale Sur les Conditions de Vie des Populations. ISTEEBU, CD-ROM.

Republic of Burundi (2003). Interim Strategic Framework for Accelerating Economic Growth and Reducing Poverty. Poverty Reduction Strategy Paper, Republic of Burundi. 
Reyntjens, F. (1993). “The Proof of the Pudding Is In the Eating: The June 1993 Elections in Burundi.” Journal of Modern African Studies, 31(4), 563-583.

Reyntjens, F. (1998). “Evolution Politique au Rwanda et au Burundi, 1997-1998.” In L'Afrique des Grands Lacs. Annuaire 1998-1999. S. Marysse and F. Reyntjens, Editors. Paris: L’Harmattan.

Reyntjens, F. and Vandeginste, S. (1997). “Burundi. Evolution Politique en 1996-1997.” In L’Afrique des Grands Lacs. Annuaire 1997-1998. S. Marysse and F. Reyntjens, Editors. Paris: L’Harmattan.

Rosenzweig, M. and Schultz, P. (1982). "Education and the Household Production of Child Health.” Yale University Economic Growth Center Working Paper No. 311.

Shemyakina, O. (2006). “The Effect of Armed Conflict on Accumulation of Schooling: Results from Tajikistan.” HiCN Working Paper 12.

Stein, A.D., Zybert, P.A., Van de Bor, M., and Lumey, L.H. (2004). “Intrauterine Famine Exposure and Body Proportions at Birth: The Dutch Hunger Winter.” International Journal of Epidemiology, 33(4), 831-836.

Stein, A.D., Kahn, H.S., Rundle, A., Zybert, P.A., Van der Pal-de Bruin, K. and Lumey, L.H. (2007). “Anthropometric Measures in Middle Age After Exposure to Famine During Gestation: Evidence From the Dutch Famine.” American Journal of Clinical Nutrition, 85(3), 869-876.

Strauss, J. and Thomas, D. (1995). “Human Resources: Empirical Modeling of Household and Family Decisions.” In Handbook of Development Economics, Volume 3A. J. Behrman and T.N. Srinivasan, Editors. Elsevier Science. 
Suri, T. and Boozer, M. (2007). "Child Labor and Schooling Decisions in Ghana.” MIT Sloan, manuscript.

Thomas, D., Lavy, V., and Strauss, J. (1996). "Public Policy and Anthropometric Outcomes in the Côte d'Ivoire." Journal of Public Economics, 61(2), 155-192.

United Nations. (1996). Report of the Secretary-General on the Situation in Burundi. Security Council, S/1996/660. United Nations. New York.

World Health Organization. (2002). World Report on Violence and Health. World Health Organization. Geneva. 
Figure 1: Spatial and Temporal Intensity of the Conflict

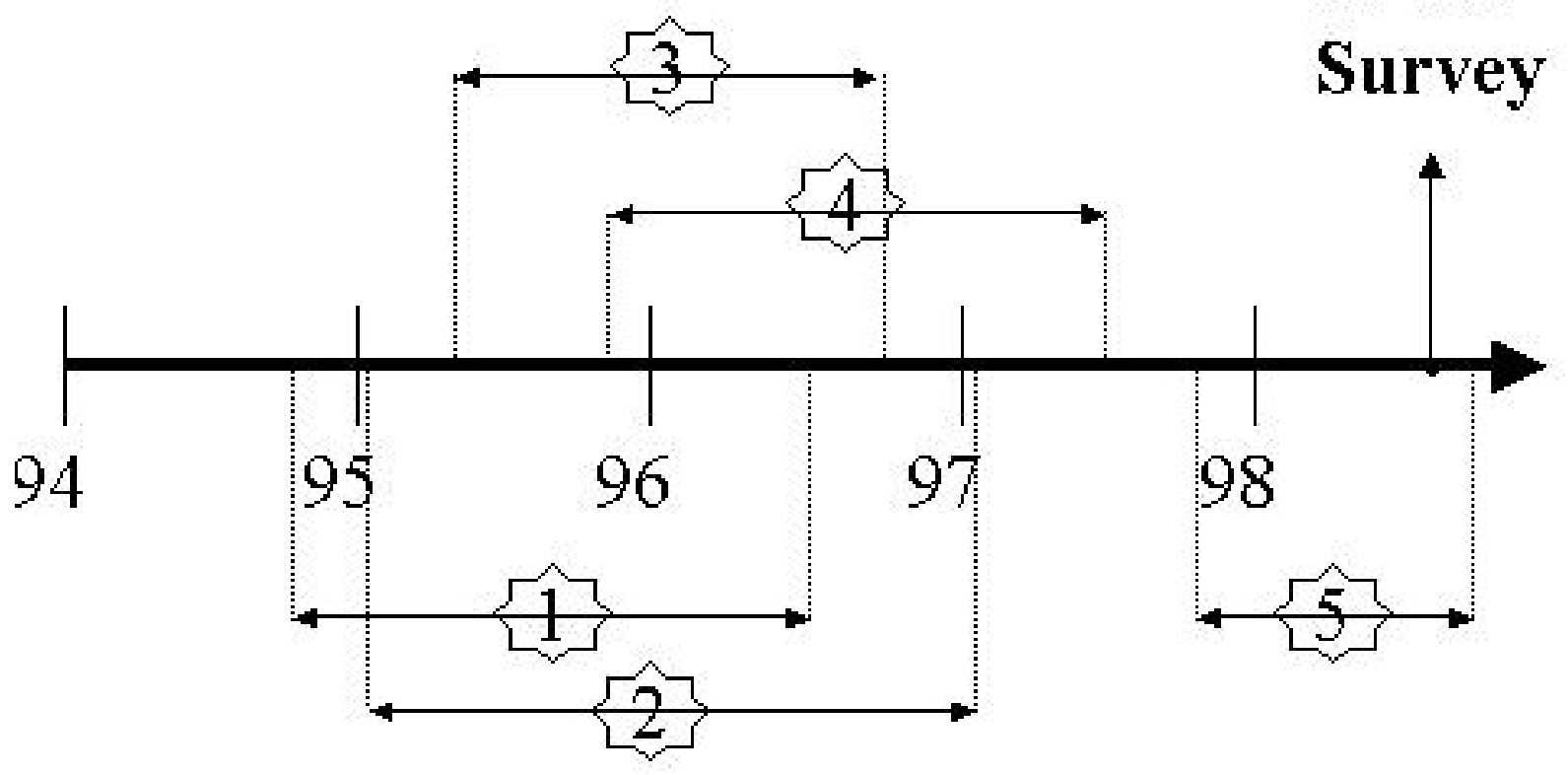

\title{
10-98:
} Survey

\author{
\{1\} Bubanza, Bujumbura Rural, Cibitoke, Ngozi \\ \{2\} Kayanza \\ \{3\} Ruyigi, Karuzi, Muyinga, Bururi \\ \{4\} Muramwya, Kirundo, Gitega \\ [5] Bubanza, Cibitoke, Bujumbura Rural
}

Notes: Group 5, which includes Bubanza, Cibitoke, and Bujumbura Rural, is not used in the main analysis since all children in these provinces are exposed. Regression results that include these three provinces are presented in Table 6 as a robustness specification. In addition, the provinces of Cankuzo and Rutana did not experience any fighting and these provinces are also excluded from the main analysis since none of the children in those provinces were exposed. Table 6 presents regression results that include these two provinces as a robustness check. Source for the figure is Chrétien and Mukuri (2000). 
Figure 2: Spread of the Civil War Across the Provinces of Burundi

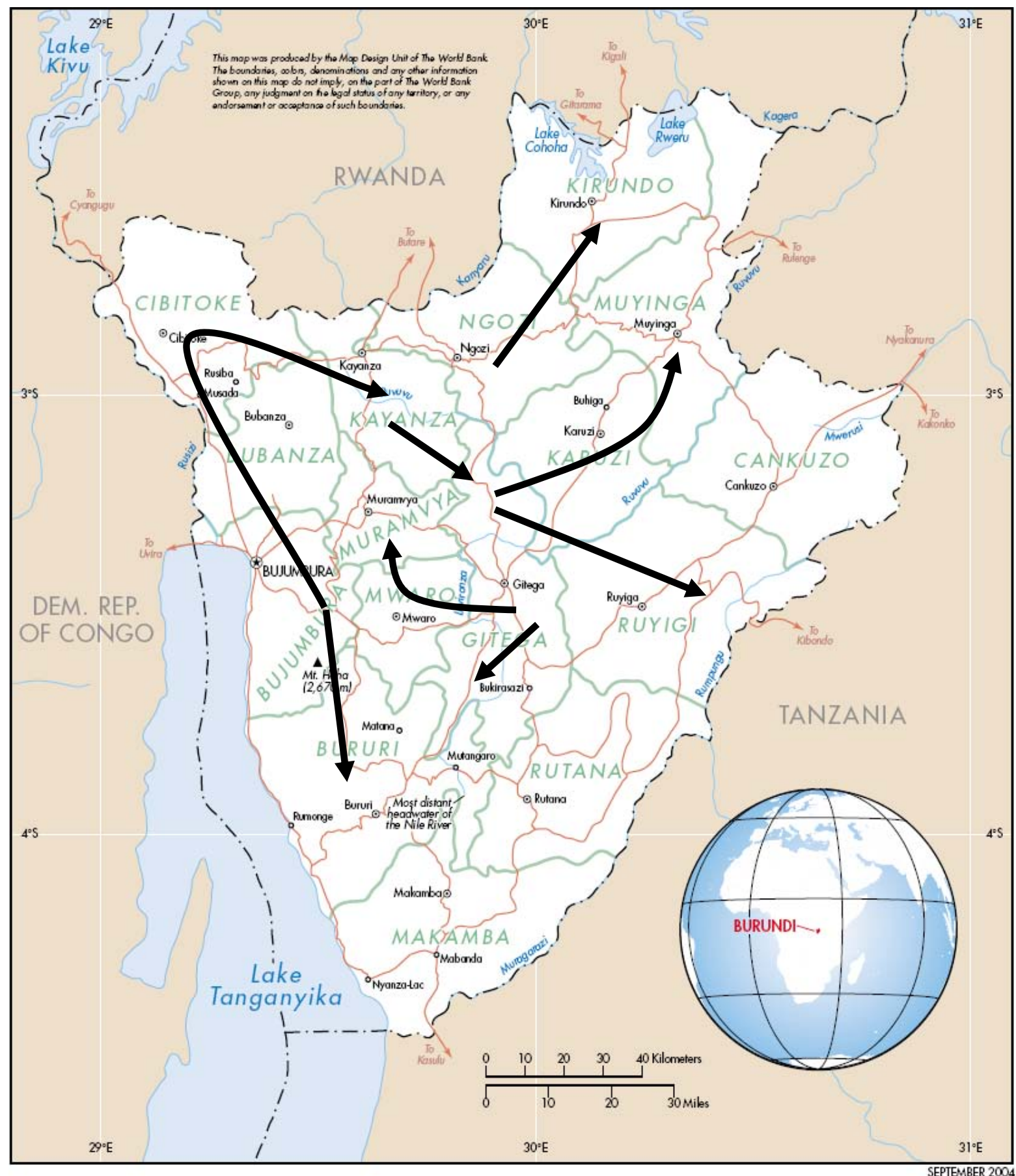

Notes: The arrows represent the spread of the civil war at the end of 1995 across the provinces of Burundi. Details to construct the spread of the war are from Chrétien and Mukuri (2000). 
Figure 3: Height for Age Z-Scores, By Months of War Exposure

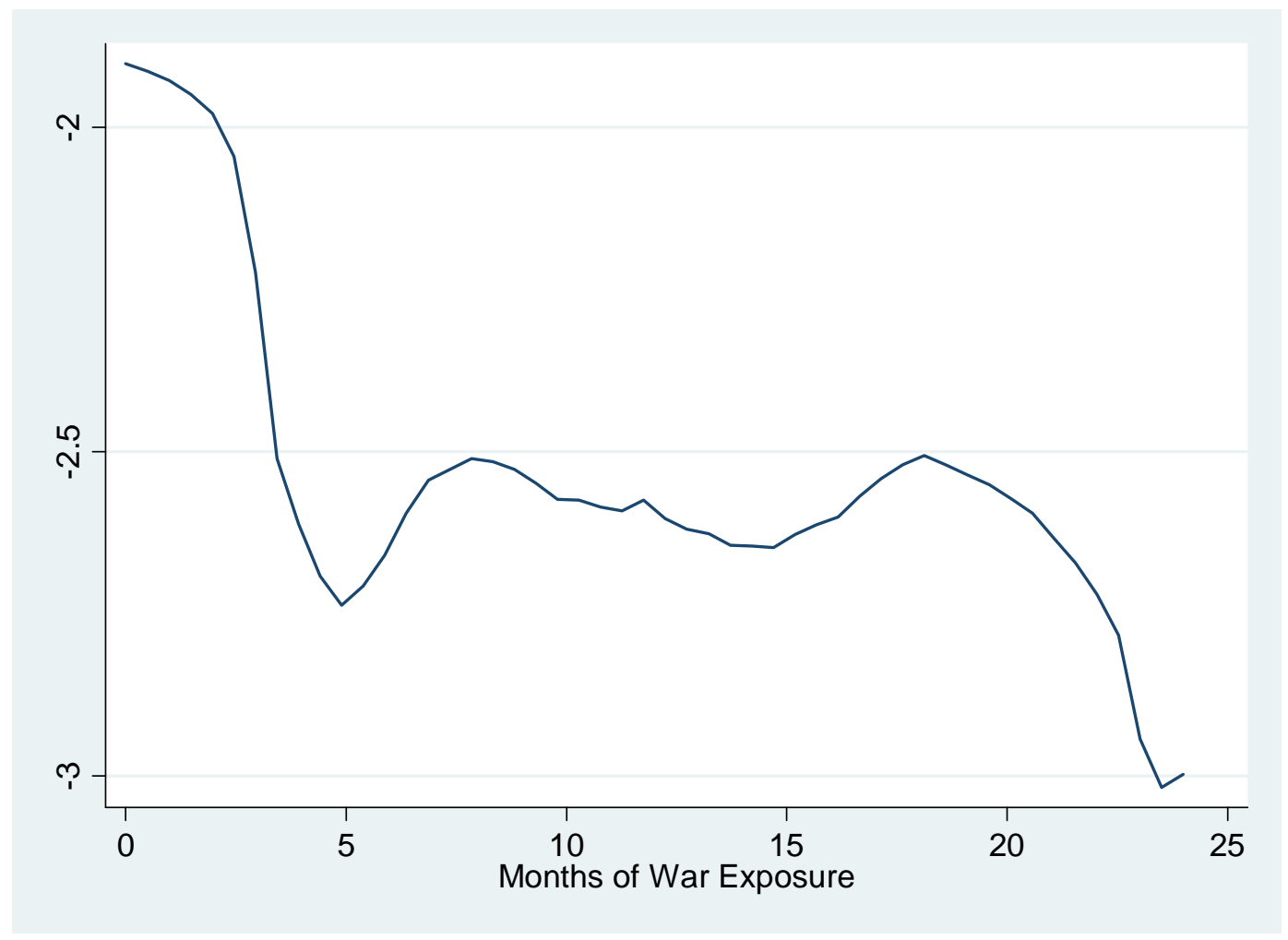

Notes: Kernel-weighted local polynomial regression (using Epanechnikov kernel) of height for age zscores on months of civil war exposure. Data source: World Bank and Burundi Statistics Institute 1998 Priority Survey. 
Table 1: Overview of Nutritional Status and Poverty, By Province

\begin{tabular}{|c|c|c|c|c|c|c|}
\hline Province & (1) & $\begin{array}{l}\text { Average } \\
\text { Height } \\
\text { for Age } \\
\text { Z-Score } \\
(2)\end{array}$ & $\begin{array}{l}\text { Not } \\
\text { Malnourished } \\
(\%) \\
\quad(3)\end{array}$ & $\begin{array}{l}\text { Moderately } \\
\text { Malnourished } \\
(\%) \\
(4)\end{array}$ & $\begin{array}{l}\text { Severely } \\
\text { Malnourished } \\
(\%) \\
\quad(5)\end{array}$ & $\begin{array}{l}\text { Poverty } \\
\text { Headcount } \\
\text { in } 1990 \\
(\% \text { Poor }) \\
\quad(6)\end{array}$ \\
\hline Bubanza & 9 & -2.48 & 43.8 & 7.3 & 48.9 & 22.4 \\
\hline Bujumbura Rural & 9 & -3.05 & 35.0 & 0.0 & 65.0 & 25.7 \\
\hline Bururi & 105 & -1.64 & 65.1 & 15.4 & 19.5 & 37.7 \\
\hline Cankuzo & 43 & -2.14 & 47.8 & 19.2 & 33.0 & 25.1 \\
\hline Cibitoke & 34 & -1.53 & 60.7 & 23.9 & 15.4 & 19.6 \\
\hline Gitega & 163 & -2.35 & 37.5 & 32.7 & 29.8 & 35.2 \\
\hline Karuzi & 85 & -2.24 & 45.0 & 15.0 & 40.0 & 66.8 \\
\hline Kayanza & 144 & -2.70 & 22.9 & 38.7 & 38.4 & 44.9 \\
\hline Kirundo & 87 & -2.37 & 35.0 & 33.6 & 31.4 & 34.0 \\
\hline Muramvya & 109 & -1.93 & 52.9 & 27.1 & 20.0 & 24.0 \\
\hline Muyinga & 121 & -2.23 & 46.6 & 17.9 & 35.5 & 27.8 \\
\hline Ngozi & 148 & -2.58 & 31.4 & 30.6 & 38.0 & 42.5 \\
\hline Rutana & 65 & -1.94 & 47.4 & 26.8 & 25.8 & 58.0 \\
\hline Ruyigi & 65 & -2.47 & 37.2 & 26.6 & 36.2 & 41.0 \\
\hline Rural Burundi & 1187 & -2.28 & 41.2 & 26.0 & 32.8 & 36.2 \\
\hline
\end{tabular}

Notes: The incidence of malnutrition is divided into three separate groups: not malnourished in which height for age z-scores are greater than -2, moderately malnourished in which height for age z-scores are between -3 and -2 , and severely malnourished in which height for age $\mathrm{z}$-scores are less than -3 . The poverty headcount measures the percentage poor in that province using 1990 pre-war data. Data source for health status: World Bank and Burundi Statistics Institute 1998 Priority Survey. Data source for poverty headcount measures: Republic of Burundi and World Bank (1995). 
Table 2: Height for Age Z-Scores, By Province, Age Distribution, Poverty Levels, and Civil War Exposure

\begin{tabular}{|c|c|c|c|}
\hline Average Height for Age Z-scores & $\begin{array}{l}\text { Child Not Exposed } \\
\text { to Civil War } \\
(\mathrm{n}=370) \\
(1)\end{array}$ & $\begin{array}{l}\text { Child Exposed to } \\
\text { Civil War } \\
(\mathrm{n}=657) \\
(2)\end{array}$ & $\begin{array}{c}\text { Mean } \\
\text { Difference } \\
(1)-(2) \\
\end{array}$ \\
\hline \multicolumn{4}{|l|}{ Panel A: By Province } \\
\hline Bururi & $\begin{array}{l}-1.157 \\
{[0.214]}\end{array}$ & $\begin{array}{l}-1.935 \\
{[0.197]}\end{array}$ & $\begin{array}{c}0.778 * * * \\
{[0.291]}\end{array}$ \\
\hline Gitega & $\begin{array}{l}-1.799 \\
{[0.209]}\end{array}$ & $\begin{array}{l}-2.604 \\
{[0.130]}\end{array}$ & $\begin{array}{l}0.805^{* * *} \\
{[0.247]}\end{array}$ \\
\hline Karuzi & $\begin{array}{l}-1.858 \\
{[0.329]}\end{array}$ & $\begin{array}{l}-2.554 \\
{[0.395]}\end{array}$ & $\begin{array}{c}0.696 \\
{[0.359]}\end{array}$ \\
\hline Kayanza & $\begin{array}{l}-2.315 \\
{[0.187]}\end{array}$ & $\begin{array}{l}-2.865 \\
{[0.133]}\end{array}$ & $\begin{array}{c}0.550^{* *} \\
{[0.229]}\end{array}$ \\
\hline Kirundo & $\begin{array}{l}-2.264 \\
{[0.225]}\end{array}$ & $\begin{array}{l}-2.413 \\
{[0.166]}\end{array}$ & $\begin{array}{c}0.148 \\
{[0.279]}\end{array}$ \\
\hline Muramvya & $\begin{array}{l}-1.129 \\
{[0.231]}\end{array}$ & $\begin{array}{l}-2.302 \\
{[0.168]}\end{array}$ & $\begin{array}{c}1.173 * * * \\
{[0.285]}\end{array}$ \\
\hline Muyinga & $\begin{array}{l}-1.619 \\
{[0.182]}\end{array}$ & $\begin{array}{l}-2.615 \\
{[0.225]}\end{array}$ & $\begin{array}{c}0.995^{* * *} \\
{[0.289]}\end{array}$ \\
\hline Ngozi & $\begin{array}{l}-2.156 \\
{[0.198]}\end{array}$ & $\begin{array}{l}-2.894 \\
{[0.138]}\end{array}$ & $\begin{array}{l}0.738 * * * \\
{[0.241]}\end{array}$ \\
\hline Ruyigi & $\begin{array}{l}-1.856 \\
{[0.239]}\end{array}$ & $\begin{array}{l}-2.815 \\
{[0.298]}\end{array}$ & $\begin{array}{c}0.959 * * \\
{[0.382]}\end{array}$ \\
\hline All Rural Provinces Burundi & $\begin{array}{l}-1.844 \\
{[0.083]}\end{array}$ & $\begin{array}{l}-2.588 \\
{[0.067]}\end{array}$ & $\begin{array}{l}0.744^{* * *} \\
{[0.107]}\end{array}$ \\
\hline $\begin{array}{l}\text { Panel B: Age Distribution } \\
\text { Child's Age (in months) }\end{array}$ & $\begin{array}{l}15.49 \\
{[0.362]}\end{array}$ & $\begin{array}{l}40.17 \\
{[0.460]}\end{array}$ & $\begin{array}{l}-24.68 * * * \\
{[0.586]}\end{array}$ \\
\hline $\begin{array}{l}\text { Average Height for Age Z-scores for } \\
\text { Young Children (<= }<4 \text { months) }\end{array}$ & $\begin{array}{l}-1.824 \\
{[0.087]}\end{array}$ & $\begin{array}{l}-2.526 \\
{[0.211]}\end{array}$ & $\begin{array}{l}0.702 * * * \\
{[0.228]}\end{array}$ \\
\hline $\begin{array}{l}\text { Average Height for Age Z-scores for } \\
\text { Old Children (> } 24 \text { months) }\end{array}$ & $\begin{array}{l}-2.065 \\
{[0.271]}\end{array}$ & $\begin{array}{l}-2.592 \\
{[0.070]}\end{array}$ & $\begin{array}{c}0.527^{*} \\
{[0.280]}\end{array}$ \\
\hline $\begin{array}{l}\text { Panel C: Province-level Poverty } \\
\text { Average Height for Age Z-scores for } \\
\text { Children in Poor Provinces }\end{array}$ & $\begin{array}{l}-1.939 \\
{[0.118]}\end{array}$ & $\begin{array}{l}-2.672 \\
{[0.104]}\end{array}$ & $\begin{array}{l}0.733^{* * *} \\
{[0.158]}\end{array}$ \\
\hline $\begin{array}{l}\text { Average Height for Age Z-scores for } \\
\text { Children in Non-poor Provinces }\end{array}$ & $\begin{array}{l}-1.713 \\
{[0.111]}\end{array}$ & $\begin{array}{l}-2.503 \\
{[0.084]}\end{array}$ & $\begin{array}{c}0.790 * * * \\
{[0.139]}\end{array}$ \\
\hline
\end{tabular}

Notes: Robust standard errors in brackets. *** significant at 1\%; ** significant at 5\%; * significant at $10 \%$. Provinces are defined as poor if the province's poverty headcount (using 1990 pre-war data) is greater than the national average of 36.2 percent. Data source: World Bank and Burundi Statistics Institute 1998 Priority Survey. 
Table 3: Percentage of Children Exposed to Civil War by Province Poverty Status

\begin{tabular}{lccc}
\hline Province Poverty Status: & $\begin{array}{c}\text { Poor } \\
\text { Provinces } \\
(1)\end{array}$ & $\begin{array}{c}\text { Non-Poor } \\
\text { Provinces } \\
(2)\end{array}$ & $\begin{array}{c}\text { Difference } \\
(1)-(2)\end{array}$ \\
\hline Percent of Children Exposed to Civil War & 60.96 & 68.02 & $-7.06^{* *}$ \\
& {$[2.61]$} & {$[2.35]$} & {$[3.51]$} \\
Number of children & 547 & 480 & \\
\hline
\end{tabular}

Notes: Robust standard errors in brackets. *** significant at 1\%; ** significant at 5\%; * significant at $10 \%$. Provinces are defined as poor if the province's poverty headcount (using 1990 pre-war data) is greater than the national average of 36.2 percent. Data source: World Bank and Burundi Statistics Institute 1998 Priority Survey. 
Table 4: Observable Characteristics Across Regions

\begin{tabular}{lccc}
\hline \hline Variables & $\begin{array}{c}\text { Early Civil } \\
\text { War } \\
\text { Provinces } \\
(1)\end{array}$ & $\begin{array}{c}\text { Late Civil } \\
\text { War } \\
\text { Provinces } \\
(2)\end{array}$ & $\begin{array}{c}\text { Difference } \\
(1)-(2)\end{array}$ \\
\hline \multirow{2}{*}{ Percentage of Literate Mothers } & 29.98 & 27.81 & 2.17 \\
& {$[2.76]$} & {$[2.07]$} & {$[3.45]$} \\
Percentage of Head of Households with Education & 31.31 & 35.01 & -3.70 \\
& {$[2.80]$} & {$[2.11]$} & {$[3.51]$} \\
Head of Household's Age & 37.83 & 38.24 & -0.41 \\
& {$[0.64]$} & {$[0.45]$} & {$[0.78]$} \\
Percentage of Head of Households Married & 88.34 & 89.14 & -0.80 \\
& {$[1.97]$} & {$[1.29]$} & {$[2.35]$} \\
Child's Age (in months) & & & \\
& 30.75 & 31.59 & -0.84 \\
Percentage of Female Children & {$[0.87]$} & {$[0.69]$} & {$[1.11]$} \\
& 54.48 & 54.25 & 0.23 \\
Civil War Conflict Shock (Percentage Exposed) & {$[3.03]$} & {$[2.24]$} & {$[3.77]$} \\
& 62.57 & 64.94 & -2.37 \\
& {$[2.94]$} & {$[2.19]$} & {$[3.67]$} \\
\hline
\end{tabular}

Notes: Robust standard errors in brackets. *** significant at $1 \%$; ** significant at $5 \%$; * significant at $10 \%$. The division between early and late civil war provinces is based on the groupings in Figure 1. Ngozi and Kayanza (groups 1 and 2 in Figure 1) are considered early civil war provinces since the war started there by January 1995. Ruyigi, Karuzi, Muyinga, Bururi, Muramvya, Kirundo, and Gitega (groups 3 and 4 in Figure 1) are considered late civil war provinces as the war did not start there until mid-1995. Results are robust to alternatively moving the group 3 provinces (where the war started in mid1995) to the early civil war category. Data source: World Bank and Burundi Statistics Institute 1998 Priority Survey. 
Table 5: Determinants of Anthropometric Outcomes in Rural Burundi

\begin{tabular}{|c|c|c|c|c|c|c|}
\hline $\begin{array}{l}\text { Dependent variable: } \\
\text { Children's Height for Age Z-Score }\end{array}$ & (1) & $\begin{array}{c}\text { Alternative } \\
\text { Conflict } \\
\text { Shock } \\
\text { Definition } \\
\text { (2) }\end{array}$ & (3) & (4) & (5) & (6) \\
\hline Civil War Conflict Shock & $\begin{array}{l}-0.618 * * * \\
{[0.214]}\end{array}$ & $\begin{array}{l}-0.435^{* *} \\
{[0.210]}\end{array}$ & $\begin{array}{l}-0.603^{* * *} \\
{[0.207]}\end{array}$ & $\begin{array}{l}-0.576^{* *} \\
{[0.228]}\end{array}$ & $\begin{array}{l}-0.551^{* * *} \\
{[0.213]}\end{array}$ & $\begin{array}{l}-0.515^{* *} \\
{[0.232]}\end{array}$ \\
\hline Female Child & & & $\begin{array}{l}0.345^{* * *} \\
{[0.088]}\end{array}$ & $\begin{array}{l}0.345^{* * *} \\
{[0.088]}\end{array}$ & $\begin{array}{l}0.349 * * * \\
{[0.090]}\end{array}$ & $\begin{array}{l}0.354^{* * *} \\
{[0.092]}\end{array}$ \\
\hline Head of Household Education & & & $\begin{array}{l}0.280 * * \\
{[0.119]}\end{array}$ & $\begin{array}{c}0.282^{* *} \\
{[0.118]}\end{array}$ & $\begin{array}{c}0.282^{* *} \\
{[0.120]}\end{array}$ & $\begin{array}{c}0.277^{* *} \\
{[0.123]}\end{array}$ \\
\hline Male-Headed Household & & & $\begin{array}{c}0.177 \\
{[0.184]}\end{array}$ & $\begin{array}{c}0.178 \\
{[0.186]}\end{array}$ & $\begin{array}{c}0.177 \\
{[0.189]}\end{array}$ & $\begin{array}{c}0.177 \\
{[0.189]}\end{array}$ \\
\hline Head of Household's Age & & & $\begin{array}{l}-0.003 \\
{[0.003]}\end{array}$ & $\begin{array}{l}-0.003 \\
{[0.003]}\end{array}$ & $\begin{array}{l}-0.003 \\
{[0.003]}\end{array}$ & $\begin{array}{l}-0.003 \\
{[0.003]}\end{array}$ \\
\hline Head of Household Married & & & $\begin{array}{l}-0.038 \\
{[0.228]}\end{array}$ & $\begin{array}{l}-0.034 \\
{[0.228]}\end{array}$ & $\begin{array}{l}-0.041 \\
{[0.230]}\end{array}$ & $\begin{array}{l}-0.032 \\
{[0.225]}\end{array}$ \\
\hline Province Fixed Effects? & Yes & Yes & Yes & Yes & Yes & Yes \\
\hline Year of Birth Cohort Fixed Effects? & Yes & Yes & Yes & Yes & Yes & Yes \\
\hline Poor Region Specific Time Trend? & No & No & No & Yes & No & No \\
\hline War Region Specific Time Trend? & No & No & No & No & Yes & No \\
\hline Province Specific Time Trend? & No & No & No & No & No & Yes \\
\hline Number of children & 1027 & 1027 & 1027 & 1027 & 1027 & 1027 \\
\hline
\end{tabular}

Notes: Robust standard errors in brackets, clustered at province level. $* * *$ significant at $1 \%$, ** significant at $5 \%$, * significant at $10 \%$. The regressions include all provinces in which some children were exposed to the war and other children were not exposed. All regressions include province dummies and year of birth dummies and are weighted using survey sampling weights. Civil war conflict shock indicates a child born in a province that experienced conflict and who was alive during the war. In column 2, regressions results use an alternative conflict shock definition in which only children aged 6 to 24 months old at the time of the civil war are considered impacted by the shock (additional details in the text). In column 4, poor province is defined as those provinces in which the 1990 pre-war poverty headcount is greater than the national average of 36.2 percent. The poor region specific time trend captures a potentially different time trend between poor and non-poor provinces. In column 5, the provinces are divided into separate war regions based on the classification in Figure 1 and the war region specific time trend captures the potentially different time trends in each war region. In column 6 , province specific time trends are included to capture potentially different time trends in each province. Data source: World Bank and Burundi Statistics Institute 1998 Priority Survey. 
Table 6: Robustness Specifications of the Determinants of Anthropometric Outcomes in Rural Burundi, Using Alternative Province Samples

\begin{tabular}{|c|c|c|c|c|c|c|}
\hline $\begin{array}{l}\text { Dependent variable: } \\
\text { Children’s Height for Age Z-Score }\end{array}$ & (1) & (2) & (3) & (4) & (5) & (6) \\
\hline Civil War Conflict Shock & $\begin{array}{l}-0.543 * * * \\
{[0.204]}\end{array}$ & $\begin{array}{l}-0.545^{* *} \\
{[0.229]}\end{array}$ & $\begin{array}{l}-0.512 * * * \\
{[0.177]}\end{array}$ & $\begin{array}{l}-0.492 * * \\
{[0.222]}\end{array}$ & $\begin{array}{l}-0.472 * * * \\
{[0.175]}\end{array}$ & $\begin{array}{l}-0.521 * * \\
{[0.220]}\end{array}$ \\
\hline Female Child & & $\begin{array}{l}0.325^{* * *} \\
{[0.084]}\end{array}$ & & $\begin{array}{l}0.374 * * * \\
{[0.089]}\end{array}$ & & $\begin{array}{l}0.348^{* * *} \\
{[0.083]}\end{array}$ \\
\hline Head of Household Education & & $\begin{array}{l}0.284^{* *} \\
{[0.115]}\end{array}$ & & $\begin{array}{l}0.245^{* *} \\
{[0.114]}\end{array}$ & & $\begin{array}{l}0.251 * * \\
{[0.109]}\end{array}$ \\
\hline Male-Headed Household & & $\begin{array}{c}0.036 \\
{[0.203]}\end{array}$ & & $\begin{array}{c}0.085 \\
{[0.192]}\end{array}$ & & $\begin{array}{l}-0.034 \\
{[0.201]}\end{array}$ \\
\hline Head of Household's Age & & $\begin{array}{l}-0.002 \\
{[0.003]}\end{array}$ & & $\begin{array}{l}-0.002 \\
{[0.003]}\end{array}$ & & $\begin{array}{l}-0.001 \\
{[0.003]}\end{array}$ \\
\hline Head of Household Married & & $\begin{array}{l}-0.125 \\
{[0.220]}\end{array}$ & & $\begin{array}{l}-0.076 \\
{[0.216]}\end{array}$ & & $\begin{array}{l}-0.150 \\
{[0.209]}\end{array}$ \\
\hline Province Fixed Effects? & Yes & Yes & Yes & Yes & Yes & Yes \\
\hline Year of Birth Cohort Fixed Effects? & Yes & Yes & Yes & Yes & Yes & Yes \\
\hline Province Specific Time Trend? & No & Yes & No & Yes & No & Yes \\
\hline Number of children & 1079 & 1079 & 1135 & 1135 & 1187 & 1187 \\
\hline
\end{tabular}

Notes: Robust standard errors in brackets, clustered at province level. *** significant at $1 \%$, ** significant at $5 \%$, * significant at 10\%. Columns 1 and 2 include the 1027 children used in the baseline regressions in Table 5 plus the children from the three provinces in which all children in those provinces were exposed to the war (Bubanza, Bujumbura Rural, and Cibitoke). Columns 3 and 4 include the 1027 children used in the baseline regressions in Table 5 plus the children from the two provinces that did not experience any fighting and so had no children exposed to the war (Cankuzo and Rutana). Columns 5 and 6 include the 1027 children used in the baseline regression in Table 5 plus the children from the three provinces in which all children were exposed to the war (Bubanza, Bujumbura Rural, and Cibitoke) plus the children from the two provinces in which no children were exposed to the war (Cankuzo and Rutana). All regressions include province dummies and year of birth dummies and are weighted using survey sampling weights. Civil war conflict shock indicates a child born in a province that experienced conflict and who was alive during the war. Province specific time trends are included to capture potentially different time trends in each province. Data source: World Bank and Burundi Statistics Institute 1998 Priority Survey. 
Appendix Table 1: Breakdown of Missing Data in Rural Sample

\begin{tabular}{lc}
\hline \hline & $\begin{array}{c}\text { Number of } \\
\text { Children }\end{array}$ \\
\hline $\begin{array}{l}\text { Total Rural Sample } \\
\text { Excluded Provinces With All Children Exposed to War } \\
\quad \text { (Bubanza, Bujumbura Rural, and Cibitoke) }\end{array}$ & 1442 \\
$\begin{array}{l}\text { Excluded Provinces With No Children Exposed to War } \\
\quad \text { (Cankuzo and Rutana) }\end{array}$ & 129 \\
\hline Total Rural Sample Not Including Excluded Provinces & 1228 \\
Children with No Height Recorded & 166 \\
Children with Height for Age Z-score Measurement Errors & 35 \\
\hline Final Sample Used in Baseline Analysis & 1027 \\
\hline
\end{tabular}

Notes: Measurement errors are defined as children with height for age z-scores less than -6 or greater than 6 . The three provinces in which all children were exposed to the war (Bubanza, Bujumbura Rural, and Cibitoke) and the two provinces in which no children were exposed to the war (Cankuzo and Rutana) were excluded from the baseline analysis. Table 6 includes robustness specifications including these provinces. Data source: World Bank and Burundi Statistics Institute 1998 Priority Survey. 
Appendix Table 2: Exploring Potential Selection Bias

\begin{tabular}{|c|c|c|c|}
\hline Variables & $\begin{array}{c}\text { Children } \\
\text { Included In } \\
\text { Analysis } \\
(\mathrm{n}=1027)\end{array}$ & $\begin{array}{c}\text { Children with } \\
\text { No Height } \\
\text { Recorded or } \\
\text { Measurement } \\
\text { Error in Height } \\
\text { for Age Z-score } \\
(\mathrm{n}=201)\end{array}$ & $\begin{array}{c}\text { Mean } \\
\text { Difference }\end{array}$ \\
\hline & (1) & (2) & (1)-(2) \\
\hline Percentage of Literate Mothers & $\begin{array}{l}29.07 \\
{[1.42]}\end{array}$ & $\begin{array}{l}28.86 \\
{[3.20]}\end{array}$ & $\begin{array}{c}0.21 \\
{[3.50]}\end{array}$ \\
\hline Percentage of Head of Households with Education & $\begin{array}{l}34.96 \\
{[1.49]}\end{array}$ & $\begin{array}{l}34.83 \\
{[3.37]}\end{array}$ & $\begin{array}{c}0.13 \\
{[3.68]}\end{array}$ \\
\hline Head of Household's Age & $\begin{array}{l}38.12 \\
{[0.34]}\end{array}$ & $\begin{array}{l}37.88 \\
{[0.80]}\end{array}$ & $\begin{array}{c}0.24 \\
{[0.84]}\end{array}$ \\
\hline Percentage of Head of Households Married & $\begin{array}{l}89.29 \\
{[0.97]}\end{array}$ & $\begin{array}{l}88.56 \\
{[2.25]}\end{array}$ & $\begin{array}{c}0.73 \\
{[2.40]}\end{array}$ \\
\hline Child's Age (in months) & $\begin{array}{l}31.23 \\
{[0.46]}\end{array}$ & $\begin{array}{l}29.74 \\
{[1.08]}\end{array}$ & $\begin{array}{c}1.49 \\
{[1.14]}\end{array}$ \\
\hline Percentage of Female Children & $\begin{array}{l}54.04 \\
{[1.56]}\end{array}$ & $\begin{array}{l}54.73 \\
{[3.52]}\end{array}$ & $\begin{array}{l}-0.69 \\
{[3.85]}\end{array}$ \\
\hline Civil War Conflict Shock (Percentage Exposed) & $\begin{array}{l}63.97 \\
{[1.50]}\end{array}$ & $\begin{array}{l}63.68 \\
{[3.40]}\end{array}$ & $\begin{array}{c}0.29 \\
{[3.71]}\end{array}$ \\
\hline
\end{tabular}

Note: Robust standard errors in brackets. *** significant at 1\%; ** significant at 5\%; * significant at $10 \%$. Data source: World Bank and Burundi Statistics Institute 1998 Priority Survey. 
Appendix Table 3: Probit Regressions Estimating Probability To Be Included in the Sample, Using Fitzgerald-Gottschalk-Moffit Regression Method

\begin{tabular}{llll}
\hline $\begin{array}{l}\text { Dependent Variable: } \\
\text { Probability to be Included in Sample }\end{array}$ & $\begin{array}{l}\text { Probit } \\
(1)\end{array}$ & $\begin{array}{l}\text { Probit } \\
(2)\end{array}$ & $\begin{array}{l}\text { Probit } \\
(2)\end{array}$ \\
\hline & 0.007 & -0.242 & -0.249 \\
Civil War Conflict Shock & {$[0.103]$} & {$[0.198]$} & {$[0.199]$} \\
& $0.975^{* * *}$ & $0.964^{* * *}$ & $0.881^{* * *}$ \\
Constant & {$[0.061]$} & {$[0.143]$} & {$[0.179]$} \\
& & & \\
& No & Yes & Yes \\
$\begin{array}{l}\text { Province Fixed Effects? } \\
\text { Year of Birth Cohort Fixed Effects? }\end{array}$ & No & Yes & Yes \\
$\begin{array}{l}\text { Province Specific Time Trend? } \\
\text { No }\end{array}$ & No & Yes \\
\hline Number of children & 1228 & 1228 & 1228 \\
\hline
\end{tabular}

Note: Robust standard errors, clustered at province level. *** significant at 1\%; ** significant at 5\%; * significant at 10\%. See Appendix A for additional details on Fitzgerald, Gottschalk, and Moffit (1998) regression method. Data source: World Bank and Burundi Statistics Institute 1998 Priority Survey. 